\title{
PENGARUH LAJU PERTUMBUHAN INFLASI, HARGA MINYAK DUNIA \\ DAN DOW JONES INDUSTRIAL AVERAGE TERHADAP INDEKS \\ HARGA SAHAM GABUNGAN YANG TERDAFTAR \\ DI BURSA EFEK INDONESIA PERIODE 2007-2011
}

\author{
Rully Putra Surya Pratama \\ Indah Kurniawati
}

\begin{abstract}
This research attempts to influence the inflation growth, the oil price dow jones industrial average to Composite Stock Price Index which is registred in indonesian stock exchange in the period of 2007-2011. The population in this research was the whole index in indonesian stock exchange (ISE). The sample was taken based on sampling purpodive. The data analysis technique used double linier regression. The dependent variable in this research was the growth of Composite Stock Price Index, while the independent variable was the inflation growth, the oil price and dow jones industrial average. The results of this research showed that the almost dependent variable used had effects for the growth of Composite Stock Price Index. The inflation rate growth variable did not have effects on Composite Stock Price Index growth, while the oil price rate variable and dow jones industrial average had effects on Composite Stock Price Index growth. Simultaneously, the independent variables examinedhere had effects on Composite Stock Price Index growth.
\end{abstract}

Keywords: Rate inflation, oil price, dow jones industrial avarage, Composite Stock Price Index.

\section{PENDAHULUAN}

Pasar modal merupakan salah satu instrumen ekonomi yang memiliki peran penting bagi perekonomian suatu negara. Pasar modal mengalami pertumbuhan yang sangat pesat seiring dengan berkembangnya investasi di sektor saham. Fungsi utama pasar modal adalah tempat bertemunya pihak yang memiliki kelebihan dana (investor) dengan pihak yang membutuhkan dana (issuer). Pertemuan tersebut membentuk suatu hubungan timbal balik menguntungkan, yaitu pihak pemberi dana menerima hasil atas dana yang diinvestasikannya sedangkan bagi pihak pengguna dana dapat mengembangkan usahanya menjadi lebih besar.

Bursa Efek Indonesia (BEI) menggunakan media cetak maupun elektronik dalam menyebarkan data pergerakan harga saham. Indikator pergerakan harga saham dapat dilihat dari beberapa indeks yang dikeluarkan oleh BEI salah satunya 
adalah Indeks Harga Saham Gabungan (IHSG). Naik-turunnya indeks harga saham gabungan dapat disebabkan oleh beberapa hal antara lain inflasi, tingkat bunga, stabilitas nilai tukar rupiah, tingkat pengangguran dan stabilitas fundamental ekonomi.

Inflasi merupakan suatu bentuk kelemahan ekonomi yang sering muncul dan dialami hampir semua negara. Inflasi merupakan keadaan dimana meningkatnya keadaan harga-harga barang secara umum dan terus menerus. Inflasi sangat berpengaruh terhadap nilai saham hal ini disebabkan dengan semakin besarnya tingkat inflasi maka akan menyebabkan penurunan investasi oleh investor dikarenakan resiko yang terlampau besar. Selain inflasi naik-turunnya indeks juga dipengaruhi oleh harga minyak dunia hal ini disebabkan karena bagi perusahaan, industri minyak merupakan sumber energi untuk melakukan kegiatan produksi. Meningkatnya harga minyak berefek langsung dengan meningkatnya biaya produksi sehingga menurunkan profitabilitas perusahaan, hal ini dapat menyebabkan nilai saham perusahaan tersebut mengalami penurunan. Penurunan DJIA juga berdampak pada penurunan IHSG yang dikarenakan pengaruh dari adanya diversifikasi saham oleh para investor sebagai wujud dari adanya globalisasi. Diversifikasi dimaksudkan untuk meningkatkan peluang untuk mendapatkan keuntungan dan meminimalkan risiko dari investasi.

Beberapa penelitian terdahulu telah dilakukan untuk mengetahui pengaruh inflasi, harga minyak dunia dan Dow Jones indutrial average (DJIA) terhadap IHSG. Hasil penelitian Pasaribu (2010) menunjukkan bahwa harga minyak dunia, nilai tukar, inflasi dan suku bunga SBI secara simultan mempengaruhi pergerakan IHSG di BEI selama periode 2006-2009. Secara parsial, harga minyak dunia berpengaruh positif dan tidak signifikan terhadap pergerakan IHSG di BEI, nilai tukar dan inflasi berpengaruh secara negatif dan tidak signifikan terhadap pergerakan IHSG di BEI, sedangkan suku bunga SBI berpengaruh negatif dan signifikan terhadap pergerakan IHSG di BEI selama periode 2006-2009.

Hasil penelitian Witjaksono (2010) menunjukan bahwa variabel tingkat suku bunga SBI dan kurs rupiah berpengaruh negatif terhadap IHSG. Sementara variabel harga minyak dunia, harga emas dunia, indeks Nikkei 225 dan indeks 
Dow Jones berpengaruh positif terhadap IHSG. Berdasar uraian tersebut, maka peneliti tertarik untuk menelaah lebih lanjut mengenai pengaruh laju pertumbuhan inflasi, harga minyak dunia dan Dow Jones industrial average terhadap indeks harga saham gabungan yang terdaftar di Bursa Efek Indonesia perioda 2007-2011.

\section{TINJAUAN PUSTAKA DAN PENGEMBANGAN HIPOTESIS}

\section{Indeks Harga Saham}

Indeks harga saham merupakan indikator utama yang menggambarkan pergerakan harga saham (Darmaji dan Fakhrudin, 2001:95). Indeks harga saham biasanya digunakan sebagai indikator trend pasar. Indeks Harga Saham Gabungan (IHSG) merupakan salah satu indeks pasar saham yang digunakan oleh Bursa Efek Indonesia (BEI).

IHSG atau Composite Stock Price Index adalah indeks atau harga rata-rata dari pergerakan harga seluruh saham biasa dan saham preferen yang tercatat di BEI. Perubahan IHSG dapat disebabkan oleh berbagai faktor, salah satu faktor utama perubahan tersebut adalah perubahan yang terjadi di lingkungan ekonomi makro. terdapat beberapa faktor ekonomi makro yang berpengaruh terhadap IHSG, antara lain:

1. Inflasi, adalah meningkatnya harga-harga barang secara umum dan terusmenerus. Menurut Fahmi (2011:186), inflasi merupakan suatu kejadian yang menggambarkan situasi dan kondisi harga barang mengalami kenaikan dan nilai mata uang mengalami perlemahan, dan jika ini terjadi secara terus-menerus maka akan mengakibatkan pada buruknya kondisi ekonomi secara menyeluruh serta mampu mengguncang tatanan stabilitas ekonomi.

2. Harga minyak dunia, merupakan salah satu sumber energi penting bagi kehidupan manusia. Minyak bumi dapat dikatakan sebagai emas hitam, hal ini dikarena warnanya yang coklat gelap namun sangat berharga bagi manusia. Minyak bumi terdapat pada lapisan kerak bumi, yang diperoleh melalui sumur minyak di pertambangan-pertambangan minyak. Lokasi sumur minyak didapatkan melalui proses studi geologi, analisis sedimen, karakter dan struktur sumber, dan berbagai macam sumber studi lainnya. 
3. Indeks DJIA, adalah salah satu indeks yang digunakan didalam New York Wall Street. DJIA didirikan Charles Dow yang merupakan editor dari The Wall Street Journal dan pendiri perusahaan Dow Jones Company. DJIA merupakan indeks tertua di Amerika yang masih berjalan. Indeks DJIA menginterprestasikan perekonomian yang terjadi di Amerika. Kenaikan pada indeks ini mencerminkan membaiknya performa perekonomian di Amerika dan sebaliknya penurunan pada indeks ini mencerminkan memburuknya performa perekonomian di Amerika.

\section{Pengaruh Inflasi terhadap Indeks Harga Saham Gabungan di BEI}

Inflasi adalah suatu keadaan saat kecenderungan harga-harga secara umum mengalami kenaikan secara terus-menerus dalam kurun waktu tertentu. Dengan adanya inflasi akan memunculkan gejolak dalam pasar modal. Hal ini disebabkan penurunan laba perusahaan yang diakibatkan oleh meningkatnya harga jual barang sedangkan penjualan mengalami penurunan. Keadaan ini akan membuat para investor menarik sahamnya hal ini disebabkan penurunan laba perusahaan. Efek dari penarikan saham para investor adalah menurunnya nilai saham perusahaan yang terdaftar di BEI yang secara langsung mengakibatkan merosotnya Indeks Harga Saham Gabung di BEI. Berdasar hal tersebut, maka hipotesis yang diajukan adalah:

$\mathrm{H}_{1}$ : Laju pertumbuhan inflasi berpengaruh terhadap IHSG

\section{Pengaruh Harga Minyak Dunia Terhadap Indeks Harga Saham Gabungan di BEI}

Perubahan harga minyak dunia akan memberikan pengaruh bagi perusahaan. Saat harga minyak dunia mengalami kenaikan hal ini akan memberikan pengaruh pada perusahaan. Perusahaan manufaktur efek dari naiknya harga minyak dunia akan meningkatkan harga pokok produksi yang akan berpengaruh pada keuntungan perusahaan sedangkan pada perusahaan tambang akan meningkatkan keuntungan. Kedua hal yang bertolak belakang tersebut akan mempengaruhi IHSG di BEI, hal ini disebabkan kedua jenis perusahaan tersebut termasuk dalam IHSG. Berdasar hal tersebut, maka hipotesis yang diajukan adalah: 
$\mathrm{H}_{2}$ : Laju pertumbuhan harga minyak dunia berpengaruh terhadap IHSG

\section{Pengaruh Indeks Dow Jones Industrial Averages terhadap Indeks Harga Saham Gabungan di BEI}

Indeks DJIA merupakan indeks tertua dan terbesar yang ada di Amerika. Secara langsung indeks ini dapat mencerminkan keadaan perekonomian yang terjadi di Amerika. Krisis yang diakibatkan oleh subprime mortagage di Amerika pada tahun 2008 menimbulkan gejolak yang besar bagi dunia hal ini juga menyebabkan penurunan indeks DJIA. Efek dari penurunan tersebut berimbas pada dunia yang mengakibatkan krisis global. Efek ini disebabkan oleh adanya diversifikasi yang dilakukan oleh investor. Pada tahun 2008, Kustodian Sentra Efek Indonesia mencatat kepemilikan modal asing di Indonesia sebesar 67\%, imbas dari besarnya presentase dari kepemilikan modal asing adalah menurunnya IHSG. Hal ini disebabkan para pemodal asing menjual sahamnya yang ada di Indonesia untuk mencari jalan aman akibat dari penurunan indeks DJIA. Kejadian ini memicu para investor lokal untuk menjual sahamnya sehingga IHSG mengalami penurunan yang drastis. Berdasar hal tersebut, maka hipotesis yang diajukan adalah:

$\mathrm{H}_{3}$ : Laju Pertumbuhan DJIA berpengaruh terhadap IHSG

\section{METODA PENELITIAN}

\section{Populasi dan Sampel}

Populasi dalam penelitian ini adalah seluruh indeks harga saham yang listing di Bursa Efek Indonesia selama periode 2007-2011. Sampel dalam penelitian ini adalah indeks harga saham gabung selama periode 2007-2011.

\section{Devinisi Operasional Variabel}

\section{Variabel Dependen}

Variabel dependen penelitian ini adalah Indeks Harga Saham Gabung. IHSG dalam penelitian ini menggunakan formula:

$$
\text { Indeks Harga Saham Gabungan } \frac{=\text { Nilai Pasar }}{\text { Nilai Dasar }} \times 100
$$




\section{Variabel Independen}

Variabel independen merupakan variabel yang akan mempengaruhi variabel dependen. Variabel independen dalam penelitian ini adalah;

\section{Inflasi (X1)}

Inflasi merupakan keadaan harga-harga barang secara umum mengalami kenaikan. Perhitungan inflasi menggunakan IHK dengan rumus (Fahmi, 2011: 190):

$$
\begin{array}{l|c|} 
& \text { IR } x=\frac{I H K_{x}}{I H K_{(x-1)}} \times 100 \%-100 \% \\
\operatorname{IR} x & =\text { Angka Inflasi (\%) bulan x } \\
I H K_{x} & =\text { Indeks Umum IHK Gabungan bulan ke x } \\
I H K_{(x-1)} & =\text { Indeks Umum IHK Gabungan bulan ke (x-1) }
\end{array}
$$

\section{Harga Minyak Dunia (X2)}

Penetapan harga minyak dunia yang digunakan dalam penelitian ini dengan mengunakan standar West Texas Intermidiate.

\section{Dow Jones Industrial Average (X3)}

Indeks Dow Jones Industrial Average merupakan indeks terbesar di Amerika yang mampu menginterprestasikan perekonomian di Amerika. Indeks ini terdiri dari 30 perusahaan besar di Amerika. Penghitungan DJIA menggunakan rumus sebagai berikut (Jogiyanto, 2007: 99) :

$$
\text { DJIA }_{t}=\frac{\sum_{i-1}^{30} P_{n}}{n-\text { disesuaikan }}
$$

Keterangan:

DJIA $_{t}=$ DJIA untuk hari ke-t

$\sum_{i=1}^{30} P_{n} \quad=$ Jumlah semua harga ke 30 saham untuk hari yang sama

$\mathrm{n} \quad=$ jumlah saham disesuaikan dengan stock split dan stock dividend 


\section{Tenik Analisis Data}

Metode analisis data dalam penelitian ini menggunakan model analisis regresi linier berganda dengan formula:

$$
\mathrm{Y}=\mathrm{a}+\mathrm{b}_{1} \mathrm{X}_{1}+\mathrm{b}_{2} \mathrm{X}_{2}+\mathrm{b}_{3} \mathrm{X}_{3}+\mathrm{e}
$$

$$
\begin{aligned}
& \text { Keterangan } \\
& \mathrm{Y}=\text { Indeks Harga Saham Gabungan } \\
& \mathrm{a} \quad=\text { konstanta } \\
& \mathrm{X}_{1}=\text { Inflasi } \\
& \mathrm{X}_{2}=\text { Harga minyak dunia } \\
& \mathrm{X}_{3}=\text { Indeks Dow Jones Industrial Averages } \\
& \mathrm{b}_{1,2,3}=\text { koefisien regresi untuk } \mathrm{X}_{1}, \mathrm{X}_{2}, \mathrm{X}_{3} \\
& \mathrm{e} \quad=\text { disturbance error } \text { (faktor pengganggu/ residual) }
\end{aligned}
$$

Namun sebelum model regresi digunakan model tersebut harus di uji terlebih dahulu dengan menggunakan uji asumsi klasik regresi yaitu pengujian normalitas, multikolinieritas, heteroskedastisitas dan autokorelasi agar model regresi benar-benar menunjukan hubungan yang signifikan dan representatif atau disebut BLUE (best linier unbiased estimator).

\section{ANALISIS DATA DAN PEMBAHASAN}

\section{Laju Pertumbuhan Inflasi Berpengaruh terhadap Laju Pertumbuhan IHSG}

Berdasar hasil pengujian, variabel bebas laju pertumbuhan inflasi sebesar 1.831 yang menunjukkan tanda negatif. Hal ini berarti pengaruh laju pertumbuhan inflasi terhadap laju pertumbuhan IHSG adalah negatif. Berdasar hasil uji t menunjukkan bahwa bahwa nilai signifikansi lebih besar dibandingkan 0,05. Dengan demikian, pengaruh laju pertumbuhan inflasi terhadap laju pertumbuhan IHSG adalah tidak signifikan secara statistik. Dengan demikian hipotesis pertama yang menyatakan bahwa laba akuntansi mempunyai pengaruh positif dan signifikan terhadap return saham tidak terbukti.

Tidak terbuktinya hipotesis pertama ini sejalan dengan penelitian yang dilakukan oleh Pasaribu (2010), inflasi berpengaruh secara negatif dan tidak signifikan terhadap pergerakan IHSG di BEI. Tidak signifikannya pengaruh 
variabel perubahan laba laju pertumbuhan inflasi terhadap variabel laju pertumbuhan IHSG dapat terjadi karena selama perioda penelitian yaitu tahun 2007-2011, Inflasi yang terjadi masih pada batas normal sehingga tidak terjadi pergolakan dalam dunia bursa.

\section{Laju Pertumbuhan Harga Minyak Dunia terhadap Laju Pertumbuhan IHSG}

Berdasar hasil pengujian, secara keseluruhan diperoleh koefisien regresi laju pertumbuhan harga minyak dunia yang menunjukkan tanda positif sebesar 0,172. Berdasarkan hasil uji $\mathrm{t}$ menunjukkan bahwa nilai signifikansi lebih kecil dibandingkan 0,05. Dengan demikian, laju pertumbuhan harga minyak dunia terhadap laju pertumbuhan IHSG adalah signifikan secara statistik. Pengujian koefisien dan berdasar hasil uji $\mathrm{t}$ ini secara keseluruhan menunjukkan bahwa terdapat pengaruh dengan arah positif dan signifikan antara laju pertumbuhan harga minyak dunia terhadap laju pertumbuhan IHSG. Dengan demikian hipotesis kedua yang menyatakan bahwa laju pertumbuhan minyak dunia mempunyai pengaruh signifikan terhadap return saham terbukti.

Terbuktinya hipotesis kedua ini sejalan dengan penelitian yang dilakukan oleh Witjaksono (2010) yaitu harga minyak dunia berpengaruh positif signifikan terhadap IHSG. Hasil ini menunjukan kenaikan harga minyak dunia akan mendorong kenaikan IHSG. Namun berbanding terbalik dengan penelitian yang dilakukan Pasaribu (2010) harga minyak dunia berpengaruh positif dan tidak signifikan terhadap pergerakan IHSG.

\section{Laju pertumbuhan DJIA terhadap Laju pertumbuhan IHSG}

Berdasarkan hasil pengujian, secara keseluruhan diperoleh koefisien regresi laju pertumbuhan DJIA yang menunjukkan tanda positif sebesar 0,841. Hasil uji t menunjukkan bahwa bahwa nilai signifikansi lebih kecil dibandingkan 0,05. Dengan demikian, pengaruh laju pertumbuhan DJIA terhadap laju pertumbuhan IHSG signifikan secara statistik. Pengujian koefisien dan berdasarkan hasil uji t ini secara keseluruhan menunjukkan bahwa pengaruh dengan arah positif antara laju pertumbuhan DJIA terhadap laju pertumbuhan IHSG signifikan secara statistik. 
Dengan demikian hipotesis ketiga yang menyatakan bahwa laju pertumbuhan DJIA mempunyai pengaruh signifikan terhadap laju pertumbuhan IHSG terbukti.

Terbuktinya hipotesis ketiga ini sejalan dengan penelitian yang dilakukan Witjaksono (2010) yang menyatakan bahwa Indeks Dow Jones berpengaruh positif signifikan terhadap IHSG dengan nilai signifikansi sebesar 0,000. Hal ini disebabkan Amerika merupakan salah satu tujuan ekspor Indonesia dan banyak para investor yang menanamkan investasinya di Amerika dan Indonesia sehingga jika terjadi pergolakan di Amerika secara langsung Indonesia akan merasakan dampaknya.

\section{SIMPULAN, KETERBATASAN, DAN SARAN}

Penelitian ini bertujuan untuk mengetahui pengaruh laju pertumbuhan inflasi, harga minyak dunia, dan DJIA terhadap laju pertumbuhan IHSG. Berdasarkan hasil analisis dan pembahasan, maka dapat simpulan bahwa:

1. Laju pertumbuhan inflasi tidak mempunyai pengaruh terhadap laju pertumbuhan IHSG.

2. Laju pertumbuhan minyak dunia mempunyai pengaruh terhadap laju pertumbuhan IHSG.

3. Laju perumbuhan DJIA mempunyai pengaruh terhadap laju pertumbuhan IHSG

Penelitian ini mempunyai beberapa keterbatasan. Keterbatasan dalam penelitian ini adalah data yang digunakan merupakan data bulanan sedangkan pergerakan pasar modal dapat terjadi setiap hari dan data yang digunakan pada laju pertumbuhan inflasi adalah inflasi yang terjadi secara nasional sehingga kurang dapat menggambarkan pengaruhnya secara langsung terhadap Indeks Harga Saham Gabungan (IHSG). Berdasar kesimpulan dari hasil analisis dan pembahasan, maka dapat direkomendasikan beberapa saran untuk penelitian berikutnya berupa menggunakan data harian dan memanjangkan periode penelitian serta menambahkan variabel lainnya. 


\section{DAFTAR PUSTAKA}

Dow Jones Industrial Average (DJIA), [Online] Didapatkan: < http://id.wikipedia.org/wiki/Dow_Jones_Industrial_Average $\quad[12>$ November 2011]

Fahmi, Irham. 2011. Analisis Kinerja Keuangan. Bandung: Penerbit Alfabeta

Imamudin, Yuliadi. 2008. Ekonomi Moneter. Jakarta: PT Indeks.

Indriantoro, Nur dan Bambang Supomo. (1999). Metodologi Penelitian Bisnis untuk Akuntansi dan Manajemen, Edisi Pertama. Yogyakarta: BPFE UGM.

Ghozali, Imam. 2006. Aplikasi Analisis Multivariat dengan Program SPSS. Semarang: Badan Penerbit Universitas Diponegoro.

Jogiyanto. 2008. Teori Portofolio dan Analisis Investasi, Edisi Kelima. Yogyakarta: BPFE.

Kurniawati, Indah. 2006. Mengolah Data Statistik Dengan SPSS 11.5. Yogyakarta: Universitas Ahmad Dahlan.

Minyak Bumi, [Online] Didapatkan: <http://id.wikipedia.org/wiki/Minyak_bumi [12 > November 2011]

Pasaribu, Tulus G. 2010. Analisis Pengaruh Harga Minyak Dunia, Nilai Tukar, Inflasi dan Suku Bunga Sertifikat Bank Indonesia terhadap Pergerakan Indeks Harga Saham Gabungan di Bursa Efek Indonesia Periode 2006 2009. Skripsi. Medan: Universitas Sumatera Utara.

Samuelson, Paul A dan William D Nordhaus. Makro Ekonomi edisi ke 14, Jakarta: Erlangga.

Santoso, Singgih. 2010. Statistik Parametrik. Jakarta: PT Elex Media Komputindo.

Susilo, Bambang. 2009. PASAR MODAL Mekanisme Perdagangan Saham, Analisis Sekuritas, dan Strategi Investasi di Bursa Efek Indonesia (BEI). UPP STIN YKPN. Yogyakarta. 
Tandelilin , Eduardus. 2007. Analisis Investasi dan Manajemen Portofolio, Edisi Pertama. Yogyakarta: BPFE.

Darmadji, Tjiptono dan Hendy M. Fakhruddin. (2006). Pasar Modal di Indonesia, Edisi Kedua. Jakarta: Salemba Empat.

Witjaksono, Ardian Agung. 2010. Analisis Pengaruh Tingkat Suku Bunga SBI, Harga Minyak Dunia, Harga Emas Dunia, Kurs Rupiah, Indeks Nikkei 225, dan Indeks Dow Jones terhadap IHSG periode 2000 - 2009. Skripsi. Semarang: Universitas Diponegoro.

\section{LAMPIRAN}

Variables Entered/Removed ${ }^{b}$

\begin{tabular}{|l|l|l|l|}
\hline Model & $\begin{array}{l}\text { Variables } \\
\text { Entered }\end{array}$ & $\begin{array}{l}\text { Variables } \\
\text { Removed }\end{array}$ & Method \\
\hline 1 & $\begin{array}{l}\text { DJIA, Inflasi, } \\
\text { Minyak } \\
\text { Dunia }^{\text {a }}\end{array}$ & & Enter \\
\hline
\end{tabular}

a. All requested variables entered.

b. Dependent Variable: IHSG

\section{Model Summary ${ }^{b}$}

\begin{tabular}{|l|r|r|r|l|l|}
\hline Model & \multicolumn{1}{|l|}{$\mathrm{R}$} & R Square & $\begin{array}{l}\text { Adjusted R } \\
\text { Square }\end{array}$ & $\begin{array}{l}\text { Std. Error of } \\
\text { the Estimate }\end{array}$ & $\begin{array}{l}\text { Durbin- } \\
\text { Watson }\end{array}$ \\
\hline 1 & $.675^{\mathrm{a}}$ & .455 & .426 & 5.99143 & 1.679 \\
\hline
\end{tabular}

a. Predictors: (Constant), DJIA, Inflasi, Minyak Dunia

b. Dependent Variable: IHSG

\section{ANOVA $^{b}$}

\begin{tabular}{|ll|l|r|r|l|l|}
\hline \multicolumn{2}{|l|}{ Model } & $\begin{array}{l}\text { Sum of } \\
\text { Squares }\end{array}$ & df & Mean Square & F & \multicolumn{1}{l|}{ Sig. } \\
\hline 1 & Regression & 1679.076 & 3 & 559.692 & 15.592 & $.000^{\mathrm{a}}$ \\
& Residual & 2010.246 & 56 & 35.897 & & \\
Total & 3689.322 & 59 & & & \\
\hline
\end{tabular}

a. Predictors: (Constant), DJIA, Inflasi, Minyak Dunia

b. Dependent Variable: IHSG 


\section{Coefficients $^{\mathrm{a}}$}

\begin{tabular}{|c|c|c|c|c|c|c|c|}
\hline \multirow[b]{2}{*}{ Model } & \multicolumn{2}{|c|}{$\begin{array}{l}\text { Unstandardized } \\
\text { Coefficients }\end{array}$} & \multirow{2}{*}{\begin{tabular}{|l|} 
Standardize \\
d \\
Coefficient \\
s \\
Beta \\
\end{tabular}} & \multirow[b]{2}{*}{$\mathrm{t}$} & \multirow[t]{2}{*}{ Sig } & Collinearity & Statistics \\
\hline & B & Std. Error & & & & Tolerance & VIF \\
\hline $\begin{array}{ll}1 & \text { (Cons } \\
& \operatorname{tant})\end{array}$ & .898 & 16.824 & & .053 & $\begin{array}{r}.95 \\
8\end{array}$ & & \\
\hline $\begin{array}{l}\text { Inflas } \\
\mathrm{i}\end{array}$ & -1.831 & 1.517 & -.124 & 1.207 & $\begin{array}{r}.23 \\
2\end{array}$ & .921 & 1.086 \\
\hline $\begin{array}{l}\text { Miny } \\
\text { ak } \\
\text { Duni } \\
\text { a }\end{array}$ & .172 & .084 & .216 & 2.036 & $\begin{array}{r}.04 \\
7\end{array}$ & .862 & 1.161 \\
\hline DJIA & .841 & .177 & .524 & 4.747 & $\begin{array}{r}.00 \\
0\end{array}$ & .800 & 1.251 \\
\hline
\end{tabular}

a. Dependent Variable:

IHSG

\section{Collinearity Diagnostics ${ }^{a}$}

\begin{tabular}{|c|c|c|c|c|c|c|c|}
\hline \multirow{2}{*}{\multicolumn{2}{|c|}{$\begin{array}{r}\text { Dime } \\
\text { Model nsion }\end{array}$}} & \multirow[b]{2}{*}{ Eigenvalue } & \multirow[b]{2}{*}{$\begin{array}{l}\text { Condition } \\
\text { Index }\end{array}$} & \multicolumn{4}{|c|}{ Variance Proportions } \\
\hline & & & & (Constant) & Inflasi & $\begin{array}{l}\text { Minyak } \\
\text { Dunia }\end{array}$ & DJIA \\
\hline \multirow[t]{4}{*}{1} & 1 & 3.553 & 1.000 & .00 & .02 & .0 & .00 \\
\hline & 2 & .440 & 2.841 & .00 & .89 & .0 & .00 \\
\hline & 3 & .006 & 25.250 & .08 & .00 &. & .04 \\
\hline & 4 & .001 & 57.904 & .92 & .09 &.( & .96 \\
\hline
\end{tabular}

a. Dependent Variable: IHSG

\section{Residuals Statistics ${ }^{\text {a }}$}

\begin{tabular}{|l|r|r|r|l|r|}
\hline & Minimum & Maximum & Mean & \multicolumn{1}{l|}{$\begin{array}{l}\text { Std. } \\
\text { Deviation }\end{array}$} & $\mathrm{N}$ \\
\hline Predicted Value & 85.0845 & 112.1728 & 101.5567 & 5.33469 & 60 \\
Residual & -16.50449 & 12.14653 & .00000 & 5.83712 & 60 \\
Std. Predicted & -3.088 & 1.990 & .000 & 1.000 & 60 \\
Value & -2.755 & 2.027 & .000 & .974 & 60 \\
Std. Residual & & & & \\
\hline
\end{tabular}

a. Dependent Variable: IHSG 
Hasil uji heteroskedastisitas:

Correlations

\begin{tabular}{|c|c|c|c|c|c|}
\hline & & Inflasi & \begin{tabular}{|l|} 
Minyak \\
Dunia
\end{tabular} & DJIA & \begin{tabular}{|l|} 
Unstandardi \\
zed Residual \\
\end{tabular} \\
\hline \multirow[t]{6}{*}{ Spearman's rho Inflasi } & $\begin{array}{l}\text { Correlation } \\
\text { Coefficient }\end{array}$ & 1.000 & -.106 & $-.281^{*}$ & .000 \\
\hline & Sig. (2-tailed) & & .420 & .030 & .996 \\
\hline & $\mathrm{N}$ & 60 & 60 & 60 & 60 \\
\hline & $\begin{array}{l}\text { Correlation } \\
\text { Coefficient }\end{array}$ & -.106 & 1.000 & .237 & -.022 \\
\hline & Sig. (2-tailed) & 420 & & .068 & .870 \\
\hline & $\mathrm{N}$ & 60 & 60 & 60 & 60 \\
\hline \multirow[t]{3}{*}{ DJIA } & $\begin{array}{l}\text { Correlation } \\
\text { Coefficient }\end{array}$ & $-.281^{*}$ & .237 & 1.000 & -.165 \\
\hline & Sig. (2-tailed) & .030 & .068 & & 209 \\
\hline & $\mathrm{N}$ & 60 & 60 & 60 & 60 \\
\hline \multirow[t]{3}{*}{$\begin{array}{l}\text { Unstandardiz } \\
\text { ed Residual }\end{array}$} & $\begin{array}{l}\text { Correlation } \\
\text { Coefficient }\end{array}$ & .000 & -.022 & $|-.165|$ & 1.000 \\
\hline & Sig. (2-tailed) & .996 & .870 & .209 & \\
\hline & $\mathrm{N}$ & 60 & 60 & 60 & 60 \\
\hline
\end{tabular}

*. Correlation is significant at the 0.05 level (2-tailed).

NPar Test untuk Uji normalitas data :

\begin{tabular}{|ll|r|}
\hline & & $\begin{array}{l}\text { Unstandardiz } \\
\text { ed Residual }\end{array}$ \\
\hline $\mathrm{N}$ & & 60 \\
Normal Parameters & a & Mean \\
& Std. Deviation & .0000000 \\
Most Extreme & Absolute & 5.83711928 \\
Differences & Positive & .079 \\
& Negative & .053 \\
Kolmogorov-Smirnov Z & -.079 \\
Asymp. Sig. (2-tailed) & .614 \\
\hline
\end{tabular}

a. Test distribution is Normal. 